\title{
Effect of Transportation and Relocation in Post-Weaning Anoestrous Primiparous Sows
}

\author{
By S. Rojanasthien \\ Department of Obstetrics and Gynaecology and Department of Clinical Chemistry, \\ College of Veterinary Medicine, Swedish University of Agricultural Sciences, Uppsala, Sweden.
}

\begin{abstract}
Rojanasthien, S.: Effect of transportation and relocation in post-weaning anoestrous primiparous sows. Acta vet. scand. 1989, 30, 1-8. - The object of this investigation was to study the clinical and endocrine responses to transportation and relocation in 8 post-weaning anoestrous sows. They had been anoestrous for at least 24 days after weaning before transportation/relocation was performed. Laparoscopy, performed at the beginning of the experiment, revealed that the ovaries contained many follicles ( $\leq 6 \mathrm{~mm}$ in diameter), but no corpora lutea. Blood samples, taken before and after transportation/relocation, showed that LH activity was low at the beginning of the experiment and increased after transportation/relocation in the majority of the sows. Peripheral plasma concentrations of oestradiol-17 $\beta$ increased 1-4 days after transportation/relocation in 6 out of 8 sows which was followed by oestrus and ovulation. Progesterone concentrations were also below the practical detection limit until the end of oestrus. This study has demonstrated that a change in environment by transportation and relocation can induce oestrus by increasing the LH activity in post-weaning anoestrous sows.
\end{abstract}

anoestrus; environment; LH; oestradiol-17 .

\section{Introduction}

Sows are normally anoestrous during lactation (Crighton \& Lamming 1969) with suppressed luteinizing hormone (LH) and ovarian activities (Palmer et al. 1965, Parvizi et al. 1976, Konavongkrit et al. 1982). Weaning results in dramatic changes of hormone secretion and reestablishment of sexual function (Cox \& Britt 1982, Edwards \& Foxcroft 1983, Rojanasthien 1988). Shaw \& Foxcroft (1985) demonstrated a significant increase in $\mathrm{LH}$ concentration in peripheral blood during the immediate 12 hour-period after weaning. Oestrus usually occurs within 3-8 days after weaning. However, the interval is longer in primiparous than in multiparous sows (Einarsson \& Settergren 1974,
Karlberg 1980). Einarsson \& Settergren (1974) reported that about $60 \%$ of primiparous sows showed oestrus within 7 days following weaning compared to more than $80 \%$ of multiparous sows. Linde et al. (1984) reported that approximately 7.7 and $4.4 \%$ of primiparous and multiparous sows, respectively, were culled because of inability to resume sexual function after weaning.

Several studies have been performed on the effect of transportation and/or relocation on peripubertal gilts (Du Mesnul du Buisson \& Signoret 1962, Signoret 1970, Kopf et al. 1984). Dalin et al. (1988) showed that $76.5 \%$ of gilts with delayed puberty had ovulatory oestrus 3.5 to 7.5 days after transportation. However, few studies have 
been made of the clinical effect of transportation and/or relocation in anoestrous sows (Paredis 1962), and information seems to be lacking on the hormonal changes in such sows.

The purpose of this investigation was accordingly to study the clinical and endocrine responses to transportation and relocation in post-weaning anoestrous primiparous sows.

\section{Materials and methods}

The animals $(n=8)$ used were primiparous crossbred sows (Swedish Landrace $\times$ Swedish Yorkshire) which had not shown signs of oestrus within 21 days after weaning following a 5 week lactation period. Sows nos. 1-5 had farrowed at the Department of Obstetrics and Gynaecology while sows nos. 6-8 were reared at pig research station located $12 \mathrm{~km}$ from the Department. The sows were housed in individual pens in a stable which also housed a boar although they were not in direct contact with the male throughout the experimental period. The sows were fed according to the Swedish breeding stock standard. The sows were 12-13 months old at farrowing and their mean body weight was $178(172-190) \mathrm{kg}$ on day 3 of lactation. Their average weight loss during lactation and weight gain after weaning were 21 (15-25) and 19 (17-23) $\mathrm{kg}$, respectively. They had nursed an average of 11.6 (11-13) piglets. Oestrus detection was performed twice daily in the presence of a boar from the day of weaning with none of the sows showing oestrus before the beginning of this experiment.

Jugular vein catheterization (Rodriguez \& Kunavongkrit 1983) was performed during the last week of lactation in sows nos. 1-5. Utero-ovarian vein catheterization (Rojanasthien et al. 1988) was performed on day 22 after weaning in sows nos. 1 and 2. Laparoscopic examination (Wildt et al. 1973) of the ovaries was performed on days 23-29 after weaning in sows nos. 1-5. None of the sows had follicles bigger than $6 \mathrm{~mm}$ in diameter or signs of corpora lutea. The day after laparoscopy, the sows were transported in a truck for about $40 \mathrm{~min}$ and thereafter housed in different individual pens at the Department.

Sows nos. 6-8 were transported from the pig research station to the Department on day 30-33 after weaning. The individual transportation was conducted between 9.0010.00 a.m. Laparoscopic examination was performed at 3-4 h after arrival to confirm that the ovaries only contained follicles $\leq 6$ $\mathrm{mm}$ in size. Jugular vein catheterization was performed after laparoscopy.

A second laparoscopy was performed in sows which had not shown oestrus within 7 days after transportation/relocation and they were treated subcutaneously with 400 IU PMSG and 200 IU HCG (Suigonan ${ }^{(\mathbb{})}$ ).

The sows were slaughtered 2 days after the end of oestrus or 7 days after PMSG/HCG treatment. The genital organs were removed and examined macroscopically within $1 \mathrm{~h}$ after slaughter. Ovaries from the animal not expressing oestrus were fixed in Bouin's fluid and histological examination was carried out according to the method described by Kunavongkrit et al (1982).

Daily blood samples $(9.00$ a. m.) were collected from the jugular vein throughout the experimental period. Additional blood samples were taken every $8 \mathrm{~h}$ (7.00 a.m.11.00 p.m.) from the jugular vein and the utero-ovarian vein in sows nos. 1 and 2 throughout the experimental period. Frequent blood samples (every $15 \mathrm{~min}$ for $6 \mathrm{~h}$ ) were taken on days $-2,0,1,2,3,5,7$ and 13 after transportation (day $0=$ day of transportation) in sows nos. 1-7 as indicated in Table 2. On the day of standing oestrus blood samples were taken every $3 \mathrm{~h}$ in all 
sows. The blood samples were collected into heparinized tubes which were immediately centrifuged, and plasma was removed and stored in plastic tubes at $-20^{\circ} \mathrm{C}$ until radioimmunoassays were performed.

The daily blood samples were analysed for the concentrations of progesterone and oestradiol-17 $\beta$. The frequent blood samples and the samples taken every $3 \mathrm{~h}$ during oestrus were analysed for the concentration of LH. The analytical methods used have earlier been validated for the porcine species (Kunavongkrit et al. 1983). The practical detection limits of the progesterone and oestradiol- $17 \beta$ assays were arbitrarily defined as the mean plus 2 standard deviation value obtained from serial determinations of these hormones in blood plasma from an oophorectomized sow. Using this criterion, the practical detection limits for progesterone and oestradiol- $17 \beta$ were $1.0 \mathrm{nmol} / 1$ and 25 $\mathrm{pmol} / \mathrm{l}$, respectively. The average $\mathrm{LH}$ level was defined as the mean of the values obtained from the frequent blood samples. The LH base level was defined as the mean plus 1 standard deviation of the values obtained from the frequent samples excluding pulses of LH. An LH pulse was defined as 2 or more, consecutive values higher than the base level plus 1 standard deviation.

Statistical analysis of the $\mathrm{LH}$ values was performed using the t-test (Swinscow 1980).

\section{Results}

\section{Clinical and morphological findings}

The clinical data of the sows are shown in Table 1. Six sows exhibited oestrus 3.5 to 7 days after transportation/relocation. The duration of the oestrus periods were 2 to 2.5 days. All sows showing oestrus ovulated and the number of ovulations was 16-22. Two sows (nos. 5 and 6) did not show oestrus within 7 days after transportation/ relocation. Laparoscopic examination revealed that their ovaries contained many small-and medium-sized follicles (up to 6

Table 1. Clinical data on 8 post-weaning anoestrous primiparous sows before and after transportation/relocation.

\begin{tabular}{lcccccc}
\hline $\begin{array}{l}\text { Sow } \\
\text { no }\end{array}$ & $\begin{array}{c}\text { Litter } \\
\text { size }\end{array}$ & $\begin{array}{c}\text { Weight loss } \\
\text { durng } \\
\text { lactation } \\
(\mathbf{k g})\end{array}$ & $\begin{array}{c}\text { Weight gain } \\
\text { from weaning to } \\
\text { transportation } \\
(\mathbf{k g})\end{array}$ & $\begin{array}{c}\text { Day after } \\
\text { weaning at } \\
\text { transportation }\end{array}$ & $\begin{array}{c}\text { Interval from } \\
\text { transportation } \\
\text { to oestrus } \\
\text { (days) }\end{array}$ & No of C L \\
\hline 1 & 11 & 20 & 20 & 30 & 5 & 17 \\
2 & 12 & 25 & 17 & 26 & 5 & 18 \\
3 & 12 & 19 & 19 & 26 & 3.5 & 18 \\
4 & 11 & 22 & $*$ & 24 & 7 & 22 \\
5 & 11 & 15 & 18 & 26 & $* *$ & 20 \\
6 & 13 & 21 & 20 & 33 & $* * *$ & - \\
7 & 11 & 23 & 18 & 33 & 4 & 16 \\
8 & 12 & 20 & 23 & 30 & 4 & 16 \\
\hline
\end{tabular}

* was not determined.

** treated with PMSG/HCG on day 7 after transportation; Showed oestrus 4 days after treatment.

*** treated with PMSG/HCG on day 7 after transportation; without subsequent response. 
$\mathrm{mm}$ in diameter), but no visible luteal tissue. Sow no. 5 showed oestrus 4 days after PMSG/HCG treatment, while sow no. 6 showed no sign of oestrus following treatment.

At post mortem examination, no abnormalities were found in the genital organs of the sows. The ovaries of sow no. 6 contained many small to medium-sized follicles $(<6$ $\mathrm{mm}$ in diameter) but no luteal tissue. The histological examination revealed 402 follicles (diameter between 1.00 and $4.99 \mathrm{~mm}$ ), $33.3 \%$ of which were judged normal. Nine out of 15 medium-sized follicles (3.00-4.99 $\mathrm{mm}$ in diameter) were atretic.

\section{Endocrine findings}

The peripheral plasma concentrations of oestradiol-17 $\beta$ and progesterone in sows nos. 1-5 were below $25 \mathrm{pmol} / 1$ throughout the post-weaning period. Sows nos. 6-8 also had as low concentrations of oestradiol- $17 \beta$ and progesterone in peripheral blood on the day of transportation. Increased oestradiol-17 $\beta$ concentrations in peripheral plasma was detected 1-4 days after transportation/relocation, which was about 3 days before standing oestrus in 6 out of 8 sows.

Several temporary elevations of oestradiol$17 \beta$ in the utero-ovarian vein were detected during the post-weaning period (before transportation/relocation) in sows nos. 1 and

2 . Increased oestradiol-17 $\beta$ concentrations were detected in utero-ovarian blood 8-16 h after transportation/relocation or $24-36 \mathrm{~h}$ earlier than in jugular blood. Oestradiol-17 $\beta$ and progesterone concentrations in blood samples taken before and after transportation/relocation in sow no. 1 are shown in Fig. 1. Sow no. 5 had increased oestradiol-17 $\beta$ concentrations in jugular vein plasma 1 day after PMSG/HCG treatment, while sow no. 6 showed no change in oestradiol- $17 \beta$ concentrations.
Average and base levels of $\mathrm{LH}$ and the number of LH pulse(s) $/ 6 \mathrm{~h}$ obtained from frequent blood samples taken before and after transportation of sows nos. 1-7 are presented in Table 2. It was not possible to analyse the frequent blood samples for $\mathrm{LH}$ in sow no. 8. As can be seen in Table 2, there was considerable variation between animals. The average and base levels of $\mathrm{LH}$ and the number of $\mathrm{LH}$ pulse(s) $/ 6 \mathrm{~h}$ of the blood samples taken 2 days (D.-2) before transportation/relocation were low in all sows except sow no. 5 which had 4 pulses $/ 6 \mathrm{~h}$ while all other had only 1-2 pulses $/ 6 \mathrm{~h}$.

Statistical analysis revealed that the majority of the sows increased their LH activity after transportation/relocation by increasing the average level, the base level and, most significantly, in the pulse frequency of LH. The highest $\mathrm{LH}$ activity was observed 1 day after transportation/relocation in the majority of the sows, thereafter the LH activity decreased prior to oestrus. Sow no. 6 had high LH activity after transportation/relocation, thereafter the LH activity decreased and she remained anoestrus until slaughter. The preovulatory LH surge obtained from blood samples taken during oestrus reached $3.5-5.8 \mu \mathrm{g} / \mathrm{l}$ at $12-16 \mathrm{~h}$ after detection of the highest oestradiol-17 $\beta$ concentration in the jugular vein.

\section{Discussion}

Post-weaning anoestrus is more common in primiparous sows than in multiparous sows. One of the most important causative factor seems to be the weight loss during lactation (Reese et al. 1982, King \& Williams 1984, Armstrong et al. 1986). Restricted feed intake depressed ovarian function through decreased hypothalamic release of $\mathrm{GnRH}$ in gilts (Armstrong \& Britt 1987). Most of the anoestrous sows in the present study lost considerable amount of weight during lacta- 


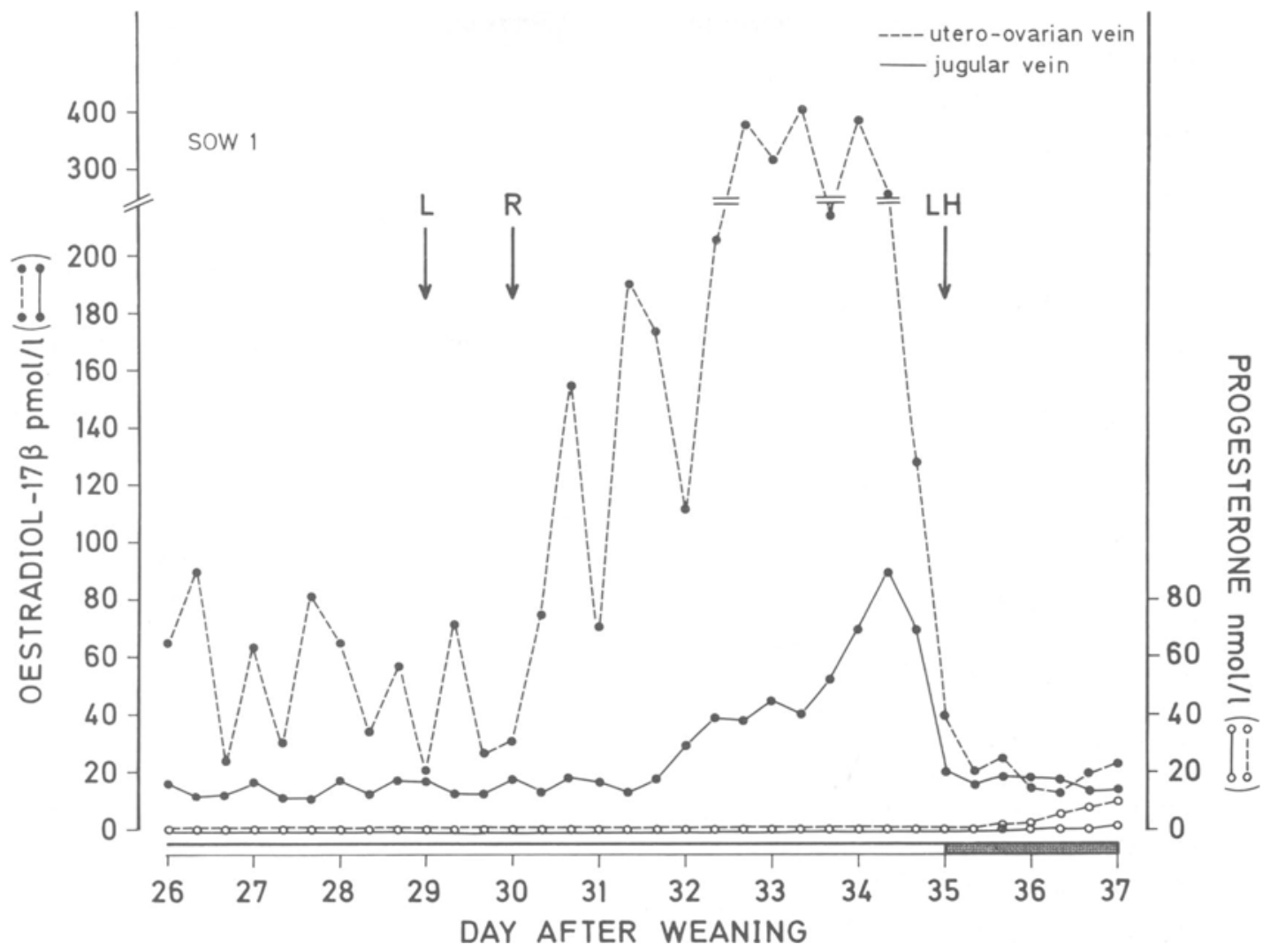

Figure 1. Plasma concentrations of oestradiol-17 $\beta(\odot)$ and progesterone $(O)$ in the utero-ovarian vein (-- ) and in the jugular vein (-) before and after transportation/relocation in sow 1 . Arrows denote the tıme of laparoscopy (L), relocation (R) and the LH surge (LH). Oestrus is indicated by the horizontal bar.

tion. The breed used here usually loses around $15 \mathrm{~kg}$ of body weight during a 5 weeks lactation period (unpublished observations). This suggests that a heavy weight loss during lactation causes decreased activity of the hypothalamo-hypophysial axis which, in turn, prolong the weaning-tooestrus interval. In the present study, the sows had, however, regained the weight they lost during lactation at the time when the experiment was performed. However, this weight gain was obviously not enough for the sows to overcome the effect of the weight loss during lactation as concerns reproductive function.

The low LH activity found here in the anoestrous sows agrees with previous findings (Almond et al. 1986a, Rojanasthien 1988). Many direct and indirect observations suggest that aberration or insufficient activity of the hypothalamo-hypophysial axis and/or higher brain centre are responsible for endocrine reproductive function in post-weaning anoestrous sows (e.g. Cox et al. 1983, Armstrong \& Britt 1985, Almond et al. 1986b). The increased LH activity following 
Table 2. Average (A) and base (B) levels of $\mathrm{LH}$ and number of $\mathrm{LH}$ pulse(s)/6 h (N) obtained from frequent samples taken before and after transportation/relocation in 7 primiparous anoestrous sows \# (mean $\pm \mathrm{SD}$ ). D. $0=$ day of transportation/relocation.

\begin{tabular}{|c|c|c|c|c|c|c|c|c|}
\hline Sow no & D. -2 & D 0 & D 1 & D. 2 & D 3 & D 5 & D 7 & D 13 \\
\hline 1 & $\begin{array}{l}\mathrm{A}=1.4 \pm 0.2^{\mathrm{a}} \\
\mathrm{B}=1.3 \\
\mathrm{~N}=2\end{array}$ & $*$ & $\begin{array}{l}1.5 \pm 0.2^{b} \\
1.5 \\
4\end{array}$ & $\begin{array}{l}1.5 \pm 0.3^{b} \\
1.5 \\
4\end{array}$ & $\begin{array}{l}1.3 \pm 0.1^{\mathrm{a}} \\
1.3 \\
2\end{array}$ & * & $*$ & * \\
\hline 2 & $\begin{array}{l}A=1.1 \pm 0.4^{a} \\
B=0.9 \\
N=1\end{array}$ & $\begin{array}{l}1.3 \pm 0.4^{\mathrm{ab}} \\
1.1 \\
2\end{array}$ & $\begin{array}{l}1.4 \pm 0.3^{b} \\
1.1 \\
5\end{array}$ & $*$ & $\begin{array}{l}1.1 \pm 0.1^{\mathrm{a}} \\
1.0 \\
2\end{array}$ & $*$ & $*$ & $*$ \\
\hline 3 & $\begin{array}{l}A=0.8 \pm 0.2^{a} \\
B=0.8 \\
N=1\end{array}$ & $*$ & $\begin{array}{l}1.1 \pm 0.1^{b} \\
1.1 \\
2\end{array}$ & $\begin{array}{l}1.0 \pm 0.1^{b} \\
1.0 \\
2\end{array}$ & $2.8 \pm 1.1^{* *}$ & $*$ & $*$ & $*$ \\
\hline 4 & $\begin{array}{l}A=0.4 \pm 0.3^{a} \\
B=0.4 \\
N=2\end{array}$ & $\begin{array}{l}0.7 \pm 0.4^{b} \\
0.7 \\
4\end{array}$ & $\begin{array}{l}0.4 \pm 0.2^{\mathrm{a}} \\
0.3 \\
2\end{array}$ & $\begin{array}{l}0.7 \pm 0.5^{b} \\
0.5 \\
3\end{array}$ & $\begin{array}{l}0.7 \pm 0.3^{b} \\
0.7 \\
4\end{array}$ & $\begin{array}{l}0.4 \pm 0.1^{\mathrm{a}} \\
0.5 \\
1\end{array}$ & $*$ & * \\
\hline 5 & $\begin{array}{l}A=1.2 \pm 0.5^{a} \\
B=0.9 \\
N=4\end{array}$ & $\begin{array}{l}0.8 \pm 0.2^{\mathrm{d}} \\
0.9 \\
1\end{array}$ & $\begin{array}{l}0.9 \pm 0.2^{c} \\
0.9 \\
2\end{array}$ & $\begin{array}{l}1.1 \pm 0.4^{\mathrm{abc}} \\
0.8 \\
3\end{array}$ & $\begin{array}{l}0.9 \pm 0.4^{\mathrm{cd}} \\
0.8 \\
1\end{array}$ & $\begin{array}{l}1.2 \pm 0.4^{\mathrm{ab}} \\
0.9 \\
3\end{array}$ & $\begin{array}{l}1.0 \pm 0.4^{\mathrm{bcd}} \\
0.9 \\
2\end{array}$ & $*$ \\
\hline 6 & $\begin{array}{l}A=* \\
B= \\
N=\end{array}$ & $\begin{array}{l}1.1 \pm 0.2^{\mathrm{a}} \\
1.1 \\
3\end{array}$ & $\begin{array}{l}1.3 \pm 0.2^{b} \\
1.3 \\
4\end{array}$ & $\begin{array}{l}0.9 \pm 0.1^{c} \\
0.9 \\
3\end{array}$ & $\begin{array}{l}0.8 \pm 0.2^{\mathrm{cd}} \\
0.7 \\
2\end{array}$ & $\begin{array}{l}0.6 \pm 0.04 \mathrm{e} \\
0.6 \\
0\end{array}$ & $\begin{array}{l}0.6 \pm 0.04 \mathrm{e} \\
0.6 \\
0\end{array}$ & $\begin{array}{l}0.7 \pm 0.1^{d} \\
0.7 \\
0\end{array}$ \\
\hline 7 & $\begin{array}{l}A=* \\
B= \\
N=\end{array}$ & $\begin{array}{l}1.0 \pm 0.1^{\mathrm{a}} \\
1.0 \\
2\end{array}$ & $\begin{array}{l}1.1 \pm 0.1^{\mathrm{a}} \\
1.1 \\
3\end{array}$ & $\begin{array}{l}0.9 \pm 0.1^{b} \\
0.9 \\
1\end{array}$ & $\begin{array}{l}0.9 \pm 0.1^{b} \\
0.9 \\
0\end{array}$ & $*$ & $*$ & $*$ \\
\hline
\end{tabular}

\# Blood samples of 1 out of 8 sows were not analysed for LH.

* Frequent blood samples were not taken.

** Blood samples were taken during surge of LH.

Values with different superscripts differ signıficantly withın animals.

transportation/relocation indicates that the hypothalamus and/or a higher brain centre of these sows responded by increased activity to this short stress. The increase in $\mathrm{LH}$ activity after transportation/relocation observed here agrees with previous findings (Armstrong \& Britt 1985) on endocrine changes associated with GnRH-induced and spontaneous oestrus in post-weaning sows. The increase in LH activity after transportation was obviously sufficient to stimulate follicular growth and induce oestrus and ovulation in the post-weaning anoestrous sows in the present study.
The effect of transportation/relocation might not have been optimal for the induction of oestrus in 2 sows. LH secretion can be depressed by administration of ACTH or hydrocortisone in gilts (Barb et al. 1982). It might be that the change in environment had a negative effect (prolonged stress) on sow no. 5 concommitantly with high level of cortisol. However, her ovaries could respond to stimulation by PMSG/HCG treatment by increasing ovarian activity and ovulation. It is not evident why sow no. 6 did not show oestrus even though she had high LH activity after transportation. The absence of $\mathrm{LH}$ 
pulse observed in this sow towards the end of the experimental period is likely responsible for the high percentage of atretic follicles in her ovaries.

It can be concluded that the LH activity of the post-weaning anoestrous sows was low. The weight gain during post-weaning period was not sufficient for the sows to overcome the long-lasting negative effect on the LH activity of a heavy weight loss during lactation. A change in environment such as transportation/relocation probably induces oestrus in most of the anoestrous sows by increasing the hypothalamo-hypophysial activity.

\section{Acknowledgements}

This work was supported by grants from the Swedish Council for Forestry and Agricultural Research. A scholarship awarded to S. Rojanasthien by the Swedish Institute is acknowledged.

\section{References}

Almond GW, Dial GD, Pressing AL, Hilley HD Pulsatıle LH release in the anestrous and cyclic sow. Proc. 9th Int. Pig Vet. Soc. Congr. 1986a, Barcelona, Spain, p. 97.

Almond GW, Dial GD, Pressing AL, Hilley HD LH response of seasonally anestrous sows to estradiol. Proc. 9th Int. Pig Vet. Soc. Congr. 1986b, Barcelona, Spain, p. 48.

Armstrong JD, Britt JH Pulsatile administration of gonadotropin-releasing hormone to anestrous sows: Endocrine changes associated with GnRH-induced and spontaneous estrus. Biol. Reprod. 1985, 33, 375-380.

Armstrong JD, Brttt JH Nutritionally-induced anestrus in gilts: Metabolic and endocrine changes associated with cessation and resumption of estrous cycles. J. Anim. Sc1. 1987, 65, 508-523.

Armstrong JD, Britt JH, Kraeling RR. Effect of restriction of energy during lactation on body condition, energy metabolism, endocrine changes and reproductive performance in primiparous sows. J. Anım. Sc1. 1986, 63, 19151925.
Barb CR, Kraeling RR, Rampacek GB, Fonda $E S$, Klser TE Inhibition of ovulation and LH secretion in the gilt after treatment with ACTH or hydrocortisone. J. Reprod. Fert. $1982,64,85-92$.

Cox NM, Britt JH Relationships between endogenous gonadotropin-releasing hormone, gonadotropıns, and follicular development after weaning in sows. Biol. Reprod. 1982, 27, 7078.

Cox NM, Esbenshade KL, Britt JH Treatment of longterm anestrous sows with estradiol benzoate and GnRH: Response of serum LH and occurrence of estrus. Thenogenology 1983, 20, 499-507.

Crighton DB, Lamming $G E$ The lactational anoestrus of the sow: The status of the anterior pituitary-ovarian system during lactation and after weaning. J. Endocr. 1969, 43, 507-519.

Dalın $A-M \cdot$ Puberty and oestrus in gilts: Clinical, morphological and endocrinological studies. (Ph.D. Thesis) Swedish University of Agricultural Sciences, Uppsala, Sweden, 1987.

Dalın A-M, Nyberg L, Eliasson $L$ The effect of transportation/relocation on cortisol, CBG and induction of puberty in gilts with delayed puberty. Acta vet. scand. 1988, 29, 207-218.

Du Mesnil du Bulsson F, Signoret JP' Influences de facteurs externes sur le déclenchement de la puberté chez la truie. (Influences of external factors on the attainment of puberty in the gilt). Ann. Zootech. 1962, 11, 53-59.

Edwards S, Foxcroft GR Endocrine changes in sows weaned at two stages of lactation. J. Reprod. Fert. 1983, 67, 161-172.

Einarsson S, Settergren I Fertility and culling in some pig breeding herds in Sweden. Nord. Vet.-Med. 1974, 11, 427-442.

Karlberg $K$ Factors affectıng postweanıng oestrus in the sow. Nord. Vet.-Med. 1980, 32, 185193.

King $R H$, Willams $I H^{\cdot}$ The effect of nutrition on the reproductive performance of first-litter sows 1. Feeding level during lactation, and between weaning and mating. Anim. Prod. 1984, 38, 241-247.

Kopf JD, Kelly CR, Zımmerman DR. Age at puperty in confinement-reared gilts as affected 
by boar exposure and relocation. J. Anım. Sci. 1984, 59, Suppl. 1, p. 121 (abstract).

Kunavongkrtt A, Einarsson S, Settergren I: Follicular development in primiparous lactating sows. Anim. Reprod. Sci. 1982, 5, 47-56.

Kunavongkrtt $A$, Kindahl $H$, Madej $A$. Clinical and endocrinological studies in primiparous zero-weaned sows: 2 . Hormone patterns of normal cycling sows after zero-weaning. $\mathrm{Zbl}$. Vet. Med. A 1983, 30, 616-624.

Linde C, Einarsson S, Pettersson $H$ Reproductive performance in gilts through their first two parities. Nord. Vet.-Med. 1984, 36, 207-214.

Palmer WM, Teague HS, Venzke WG Macroscopic observations on the reproductive tract of the sow during lactation and early postweaning. J. Anım. Sci. 1965, 24, 541-545.

Pared $l s F \cdot$ Fertility and artificial insemination in pigs. Int. J. Fert. 1962, 7, 223-233.

Parvizl $N$, Elsaesser $F$, Smidt $D$, Ellendorf $F$ Plasma luteinızıng hormone and progesterone in the adult female pig during the oestrous cycle, late pregnancy and lactating and after ovariectomy and pentobarbitone treatment. J. Endocr. 1976, 69, 193-203.

Reese DE, Moser BD, Peo ER, Lewis AJ Jr, Zımmerman $D R$, Kinder JE, Stroup $W W$. Influence of energy intake during lactation on the interval from weanıng to first estrus in sows. J. Anım. Sc1. 1982, 55, 590-598.

Rodriguez $H$, Kunavongkrit $A$. Chronic venous catheterization for frequent blood sampling in unrestrained pigs. Acta vet. scand. 1983, 24, 318-320.

Rojanasthen $S$. LH-patterns in jugular plasma and oestradiol-17 $\beta$ and progesterone in uteroovarian and jugular plasma of primaparous sows around weaning. J. Vet. Med. A 1988, 35, 498-505.

Rojanasthien S, Henriksson A, Seguin BE, Einarsson $S$ : Utero-ovarian vein catheterization in the pig: Blood levels of oestradiol-17 $\beta$ and progesterone durıng follicular and early luteal phases in the gilt. J. Vet. Med. A 1988, 35, 24-30.

Signoret JP Reproductive behaviour of pigs. J. Reprod. Fert. 1970, Suppl. 11, 105-117.

Shaw HJ, Foxcroft GR Relationships between LH, FSH and prolactin secretion and reproductive activity in the weaned sows. J. Reprod. Fert. 1985, 75, 17-28.

Swinscow TDV. In Statistics at square one. British Medical Association, London, 1980, 86 pp.

Wuldt DE, Fujımoto S, Spencer JL, Dukelow WR Direct ovarian observation in the pig by mean of laparoscopy. J. Reprod. Fert. 1973, 35, 541 -543 .

\begin{abstract}
Sammanfattning
Effekten av transport och flyttning på ungsuggor som inte visat brunst efter avvänjningen.

Avsikten med denna undersökning var att studera de kliniska och endokrina effekterna av transport och flyttnıng på 8 ungsuggor som inte visat brunst inom 24 dagar efter avvänjnıngen. Laparoskopiundersöknıng visade att äggstockarna innehöll ett flertal småfollıklar ( $\leq 6 \mathrm{~mm}$ i diameter) men saknade gula kroppar. Blodprov, som togs före och efter transporten/flyttnıngen, visade att $\mathrm{LH}$ aktıviteten var låg vid försökets början och ökade efter transporten/flyttningen hos flertalet suggor. Per1fera blodplasmanıvåerna av östradiol-17 $\beta$ var lägre än detektionsgränsen vid försökets början men steg 1-4 dagar efter transporten/flyttningen hos 6 av 8 suggor. Dessa 6 suggor visade brunst och ovulerade. Progesteronnivåerna var under detektionsgränsen ända tıll slutet av brunsten. Denna studie har visat att en förändring i mıljön i form av transport och flyttning kan framkalla brunst genom en ökning 1 LH aktiviteten hos suggor som inte visat brunst efter avvänjningen.
\end{abstract}

(Accepted Aprll 8, 1988).

Reprints may be requested from: Stig Einarsson, Dept. of Obstetrics and Gynaecology, Swedish University of Agricultural Sciences, P. O. Box 7039, S-750 07 Uppsala, Sweden. 